\title{
Effect of Climate Change on Cocoa Production in Ondo State, Nigeria.
}

\author{
Owoeye, R.S. * and A.B. Sekumade ${ }^{2}$ \\ ${ }^{1}$ Department of Agricultural and Resource Economics, Federal University of Technology, Akure, Ondo State, \\ Nigeria; Owoeye, R.S. (donetal13@yahoo.com) \\ ${ }^{2}$ Department of Agricultural Economics and Extension, Ekiti State University, Ado - Ekiti, Nigeria \\ (bosedeseku@yahoo.com) \\ *Corresponding Author - Email: donetal13@yahoo.com, Tel.: +2348038662142
}

\section{Abstract}

This study was carried out on effect of climate change on cocoa production in Ondo State, Nigeria. It specifically identified the socio-economic characteristics, examined the coping strategies adopted by the farmers in adjusting to these problems, determined the factors affecting the coping strategies adopted by the farmers in adapting to climate change, examined the rainfall and temperature patterns of the study area within the period of $1992-2012$ and analyzed the effects of some climatic variables on cocoa production within the period of 1992-2012. Multi-stage sampling technique was employed to obtain data from 180 cocoa farmers that were purposively selected from 3 Local Government Areas in Ondo State being the highest producers it the State, these are; Ondo East, Akure South and Idanre LGA. Descriptive Statistical Analysis, Trend Analysis, Multiple Regression Model and Tobit Regression Modelwere used to analyze the data. About $62 \%$ of the cocoa farmers interviewed observed noticeable changes in temperature while $70 \%$ and $51 \%$ of the farmers reported increased changes in rainfall and sunlight respectively. Among the most prevalent climate change problems reported among cocoa farmers in the study area were; high incidence of black pod disease $(80 \%)$, death of cocoa trees $(75 \%)$, increase malaria incidence $(65 \%)$,reduction in cocoa yield (63\%) and inability to dry cocoa pods (61\%). The trend analysis of cocoa production in the study area revealed that there was a sharp decrease in the volume of cocoa produced from 1992-2000while fluctuatingoccurrenceswere witnessed in the volume of cocoa produced till 2012. Also, there was variability in the rainfall, relative humidity and temperature patterns examined within the period under the study. The major coping strategies employed by the cocoa farmers in the study area were; use of chemicals (75\%), mulching and planting trees (69\%) different planting date $(63 \%)$, monitoring weather $(61 \%)$ and crop diversification $(58 \%)$ while factors influencing coping strategies adoption by the cocoa farmers in the study were; level of education, farm size, access to extension service and farming experience.

Keywords:Cocoa Production, Climate Change, Trend Analysis, Multiple Regression, Tobit Regression Model.

\section{Introduction}

Cocoa belongs to the family Steruliacaeaand genus theobroma. It is a perennial tree crop grown in tropical climate with over 66 percent produced by smallholder farmers in West Africa. Since the introduction of the crop into Nigeria in about 1874 (Oyedele, 2007), it has grown to be a major export crop. Nigeria is the third largest producer of cocoa in Africa, producing about $12 \%$ of the total world production behind Ivory Coast which produces 35 percent and Ghana's 13 percent (Wilcox and Abbot, 2004). At present, the production capacity of cocoa in Nigeria has reached about 385,000 metric tons per annum, an increase of 215,000 metric tons from year 2000 production level. This disposition places Nigeria as the fourth highest cocoa producing nation in the world after Ivory Coast, Indonesia and Ghana (Erelu, 2008). By Implication, Nigeria competes favourably with other frontline producing nations in supplying the world market. However, the production of this export crop in Nigeria has suffered a reduction in recent years owing to a number of factors (Oluyole and Sanusi, 2009).Among the most pressing limiting factors is climate change.

Climate change has taken a centre point in the midst of diverse threatening environmental challenges facing the earth now. It is arguably the most threatening environmental problem of our time, stimulating discourses vis-à-vis the causes, long term effects, as well as how to forestall the lingering and frustrating impacts. The effects of climate change is more pronounced in African societies because of its geography, its sole dependence on Agriculture and its generalized 
incapacity to cope and adapt to climate extreme (FAO,2003; Bolaji-Olatunjietal.,2010). Adverse effects of climate change continue to be a major threat to rural livelihoods (Pouliott et.al, 2009). Climate change imposes constraints to development especially among smallholder farmers whose livelihoods mostly depend on rain-fed agriculture (IPCC, 2007; Tanner and Mitchell, 2008). In Nigeria, increased agricultural production is a necessary impetus for rural poverty alleviation. However, climate change is notable among the major constraints that are to be addressed (FGN, 2004). This is so because adequate weather conditions are necessary for crop production. Recently, persistent drought, flooding, off-season rain and dry spells have disrupted crop growing seasons in many Nigeria agro-ecological zones (Medugu, 2009). Since agriculture in Nigeria is mostly rain-fed, it follows therefore that any change in climate is bound to impact productivity in particular and other socio-economic activities in the country. The impact could, however be measured in terms of effects on crop growth, availability of soil water, soil erosion, incidence of pest and diseases and decrease in soil fertility (Adejuwon, 2004).

Among the most limiting factor to cocoa production is climate change. This is because every stage of cocoa production requires adequate weather conditions (Nabuurset al., 2007). Also cocoa is highly susceptible to drought, and pattern of its cultivation is related to rainfall distribution (AnimKwapong and Frimpong, 2005).A number of factors have interrelated impact on the growth of Cocoa plant. These factors range from weather element of rainfall, temperature, sunlight and humidity to others such as soil nutrient status, pest and diseases, farmers planting practices and so on. Cocoa is known to produce well with minimal but sustained water availability throughout the year (Obatoluet al., 2003).

Black pod diseases account for quite a lot of cocoa production losses by attacking the ripened or very young pods (Opokuet al, 1999). The diseases are closely related to the pattern of rainfall distribution. It is more prevalent in damp situations with utmost pod infection in years when the short dry period from July to August is very wet. In terms of capacity, Ondo state is rated as the largest cocoa producing state in Nigeria (Oluyole, 2005).And being the largest cocoa producer in Nigeria; it has records of fluctuations in some climatic parameters, especially rainfall, temperature and sunshine hours. Nigeria Meteorological Agency (NIMET) (2011) noted that in August 2010, some places in the South West including Ondo state recorded rainfall values that were 200-300 percent higher than normal. This study tries to find out the way climate change may affect cocoa production in Ondo State, Nigeria.

\section{Methodology}

Study area: The study was carried out in Ondo state, Nigeria. Ondo State is characterized by tropical climate with rainy season from April to October, while the dry season is from November to March. The state is within tropical rain forest with mean rainfall of about $1,634 \mathrm{~mm}$ per annum and 4 months of dry season. The humidity and temperature are relatively high. The area is known to be producing the largest tonnage of cocoa in the country. The major occupation of people in the area is cultivation of cash crops with cocoa being the main crop, but often intercropped with kolanut, oil palm, plantain and banana. Also food crops like cassava, maize, yam, cassava, plantain, cocoyam and vegetables are cultivated.

Sampling technique and sampling size: Multistage sampling procedure was employed. In the first stage, three local Government Areas (LGAs) were purposively selected out of the eighteen Local Government Areas in Ondo state being the highest producers of Cocoa in the State, these are; Ondo East, Akure South and Idanre LGA. In the second stage, three communities were randomly selected from each LGA using simple random sampling technique. In the third stage, 20 farmers were selected from each community using simple random sampling and thus, making a total of 180 cocoa farmers from the three LGAs.

Sources of Data: Primary and secondary data were used for this research. The primary data were sourced through personal interview and administration of well-structured questionnaire on cocoa farmers in the study area. The questionnaire was used to obtain relevant information based 
on the objective of the research. Secondary data on weather variables were collected from the meteorological department of Ondo State Ministry of Agriculture and cocoa output from the output department.

Data Analytical Techniques: The data analytical tools used in this study comprised of descriptive statistical techniques, Trend analysis, multiple regression model and Tobit regression model. While Descriptive Statistical Technique was used to analyze the socioeconomic variables of the Cocoa farmers, Trend analysis was used to examine trend of cocoa output and climatic variables between 1992-2012 in the study area. Regression analysis was also employed to estimate the effect of some climatic variables on cocoa output while Tobit model was applied to analyze the factors influencing the coping strategies adopted by the farmers to mitigate climate change effects in the study area.

TheRegression model: This is stated in an implicit form is specified as:

$Y i=\beta_{0}+\beta_{1} X_{1}+\beta_{2} X_{2}+\beta_{3} X_{3}+\beta_{4} X_{4}+\beta_{5} X_{5}+e i$

Where:

$Y_{i}=$ output of cocoa in $(\mathrm{kg})$

$\beta_{0}=$ constant

$\beta_{i}=$ estimated coefficients of the explanatory variables

$X_{i}=$ explanatory variables

Where

$X_{i}=X_{1} \ldots \ldots \ldots \ldots . . . . .$.

$\mathrm{X}_{1}$ = Maximum temperature $\left(0^{\mathrm{C}}\right)$

$\mathrm{X}_{2=}$ Minimum temperature $\left(0^{\mathrm{C}}\right)$

$\mathrm{X}_{3}=$ Rainfall $(\mathrm{mm})$

$\mathrm{X}_{4}=$ Relative Humidity (\%)

$\mathrm{X}_{5}=$ Rainy days (numbers)

$\mathrm{e}_{\mathrm{i}}=$ Error Term

TobitRegression Model:This was used in the study because it measures both the probability of use of coping practices and the intensity of use of such practices. The Tobit model assumes that use of coping practices is a continuous decision. It expresses farmer's use of coping practices as a function of linear combination of observable explanatory variables, some unknown parameters, and an error term $\left(\mathrm{e}_{\mathrm{i}}\right)$. The major strength of Tobit model over other econometric models, such as the Ordinary Least Square (OLS) for estimation of adoption, is its inclusion of observations with non-use of coping practices. In its simplest form, the Tobit model is presented as:

$Y_{i}^{*}=\beta X_{i}+\mu_{i}$

Algebraically expressed for the ith farmer, the Tobit model is explicitly expressed as:

$Y_{i}^{*}=\beta_{0}+\beta_{1} X_{1}+----\beta_{n} X_{n} i=1 \ldots \ldots \ldots . . .$.

Where:

$Y_{i}^{*} \quad$ is the observed dependent variable i.e. adaptation to climate change, measured in the number of coping practices used by a farmer divided by numbers of probable coping strategies adopted by individual cocoa farmers.

$\beta_{0}$ is the intercept or the level of adaptation that will occur regardless of the level of independent variable. 
$\beta_{1} \ldots \ldots \beta_{n}$ are coefficient of the independent variables.

$X_{1} \ldots . . X_{n}$ are the independent variables (i.e. age, household size, marital status, sex, access to extension service,farm size,educational level, involvement in non-farming activities, farming experience, membership of cooperative society)

\section{Results and Discussion}

Socio-Economic Characteristics of Cocoa Farmers: The analysis of the socio-economic characteristics of the respondents is presented in Table 1. The study revealed that the respondents were mostly male with majority of them married and relatively old people with about 60 percent having ages more than or equal to 50 years but with large household size. This has negative implication for farming activities. It was also revealed that the major occupation of the respondents was mainly farming and they were well experienced but with relatively low education since about 30 percent had secondary education and above. The average farm size was found to be 5.95 ha implying that the cocoa farmers in the study operated on a fairly small-medium scale.

Table 1: Analysis of socio-economic characteristics of the respondents

\begin{tabular}{|l|l|l|l|}
\hline Item & & Frequency & Percent \\
\hline Sex & & 32 & 17.78 \\
Female & 148 & 82.22 \\
\hline Male & & & \\
$30-39$ & 22 & 12.22 \\
$40-49$ & 50 & 27.78 \\
$50-59$ & & 64 & 35.56 \\
60 and above & 44 & 24.44 \\
Mean & 52.03 & & \\
SD & 9.75 & & \\
\hline Marital Status & & & \\
Single & & 12 & 6.67 \\
Married & & 130 & 72.22 \\
Divorced & 21 & 11.67 \\
Widowed & & 9.44 \\
\hline Educational level & 17 & \\
No formal education & & & 12.78 \\
Some primary education & & 23 & 16.67 \\
Primary education & & 30 & 15.00 \\
Some secondary education & & 27 & 25.55 \\
Secondary education & & 46 & 23.33 \\
Tertiary education & & 12 & 6.67 \\
& & & \\
\hline Household size & & & \\
\hline
\end{tabular}




\begin{tabular}{|c|c|c|c|}
\hline $\begin{array}{l}1-4 \\
5-8 \\
9-12 \\
13 \text { and above } \\
\text { Mean } \\
\text { SD }\end{array}$ & $\begin{array}{l}6.46 \\
2.45\end{array}$ & $\begin{array}{l}7 \\
93 \\
68 \\
12\end{array}$ & \begin{tabular}{|l|}
3.89 \\
51.67 \\
37.78 \\
6.67
\end{tabular} \\
\hline $\begin{array}{l}\text { Primary Occupation } \\
\text { Farming } \\
\text { Civil service } \\
\text { Artisan } \\
\text { Trading/Business } \\
\text { Contractor } \\
\text { Others }\end{array}$ & & $\begin{array}{l}128 \\
6 \\
4 \\
28 \\
7 \\
7\end{array}$ & $\begin{array}{l}71.11 \\
3.33 \\
2.22 \\
15.56 \\
3.89 \\
3.89\end{array}$ \\
\hline $\begin{array}{l}\text { Farm size } \\
<5 \text { ha } \\
5-10 \text { ha } \\
>10 \text { ha } \\
\text { Mean } \\
\text { SD }\end{array}$ & $\begin{array}{l}5.95 \\
3.39\end{array}$ & $\begin{array}{l}82 \\
81 \\
17\end{array}$ & $\begin{array}{l}45.56 \\
45.00 \\
9.44\end{array}$ \\
\hline $\begin{array}{l}\text { Farming Experience } \\
<15 \\
15-25 \\
>25 \\
\text { Mean } \\
\text { SD }\end{array}$ & $\begin{array}{l}27.97 \\
9.95\end{array}$ & $\begin{array}{l}14 \\
72 \\
94\end{array}$ & $\begin{array}{l}7.78 \\
40.00 \\
52.22\end{array}$ \\
\hline
\end{tabular}

Source: Field Survey, 2013

\section{Table 2: Examining Farmers' forms of Climate Change Noticed}

Table 2 below revealed the result on the different forms of climate change noticed by the cocoa farmers in the study area. Most of the farmers (53.89\%) noticed the temperature has increased while $16.67 \%$ noticed the temperature to be decreasing. Also, $18.33 \%$ said temperature had stayed/remained the same while only $11.11 \%$ of the remaining respondents reported that they did not know whether or not there was a change in temperature. In the same vein, $43.89 \%$ of the respondents observed a noticeable decrease in rainfall patterns over the past 20 years while $37.22 \%$ of the respondents noticed an increase in rainfall patterns for the periods under study. Also, $12.77 \%$ of the farmers reported that rainfall patterns had stayed the same while $6.11 \%$ of the remaining respondents said they did not know. It was also made known through the result that $41.67 \%$ of the respondents confirmed an increase in sunlight's intensity while $33.33 \%$ noticed a decrease in sunlight. Only $12.22 \%$ of the respondents said sunlight had remained the same 
whereas $12.77 \%$ reported they did not know whether or not there were changes in the amount of sunlight.

\section{Table 2: Forms of Climate Change Noticed}

\begin{tabular}{|l|l|l|}
\hline Climate Change Variables & Frequency & Percentage \\
\hline Temperature & & \\
\hline Stayed the same & 33 & 18.33 \\
\hline Increased & 97 & 53.89 \\
\hline Decreased & 30 & 16.67 \\
\hline Do not know & 20 & 11.11 \\
\hline Rainfall & & \\
\hline Stayed the same & 23 & 12.77 \\
\hline Increased & 67 & 37.22 \\
\hline Decreased & 79 & 43.89 \\
\hline Do not know & 11 & 6.11 \\
\hline Sunlight & & \\
\hline Stayed the same & 22 & 12.22 \\
\hline Increased & 75 & 41.67 \\
\hline Decreased & 60 & 33.33 \\
\hline Do not know & 23 & 12.77 \\
\hline
\end{tabular}

Source: Field Survey, 2013

\section{Climate change related problems among cocoa farmers in the study area}

Figure 1 shows the result of multiple responsesof cocoa farmers as they indicated their different climatic change related problems in the study area. It can be deduced from the result that $76.80 \%$ of the respondents indicated higher incidence of black pod disease as the major problem militating against them while $69.5 \%$ reported that death of cocoa trees was the major problems they were facing. This was closely followed by $60.75 \%, 59.5 \%, 52.5 \% 51.5 \% 50 \%$ and $48 \%$ of the respondents who reported increased malaria incidence, reduction in cocoa yield, inability to dry cocoa pods, inability to spray cocoa pods, difficulties in weed control and increase in pest infestation respectively. Also, $35.75 \%, 25.85 \%, 15 \%$ and $2.5 \%$ of the remaining respondents reported that they were faced with the challenges of higher incidence of wildlife, scarcity of drinking water, scarcity of cooking water and higher incidence of cholera respectively.

Figure 1: Analysis of Climate change related problems among cocoa farmers 


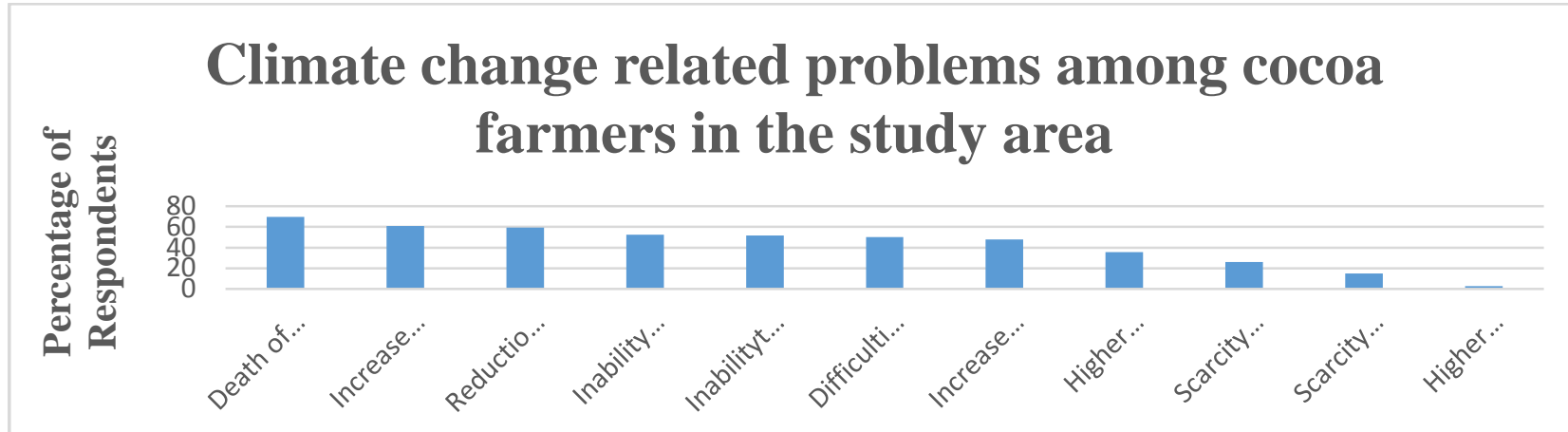

Climate change problems

*Multiple responses

Source: Field Survey, 2013

\section{Analysis of Trend in Cocoa Production in the study area}

The production record of cocoa fromOndo state as shown in figure 2 reported trend of cocoa production from 1993 to 2012. It showed a decreasing trend from 1993 to 1999 with year 2000 having the lowest production. The figure also showed dwindling and fluctuating occurrences along the production path with year 2009 having the highest output.

\section{Figure 2: Trend Analysis for Cocoa Production in the study area: 1993-2012}

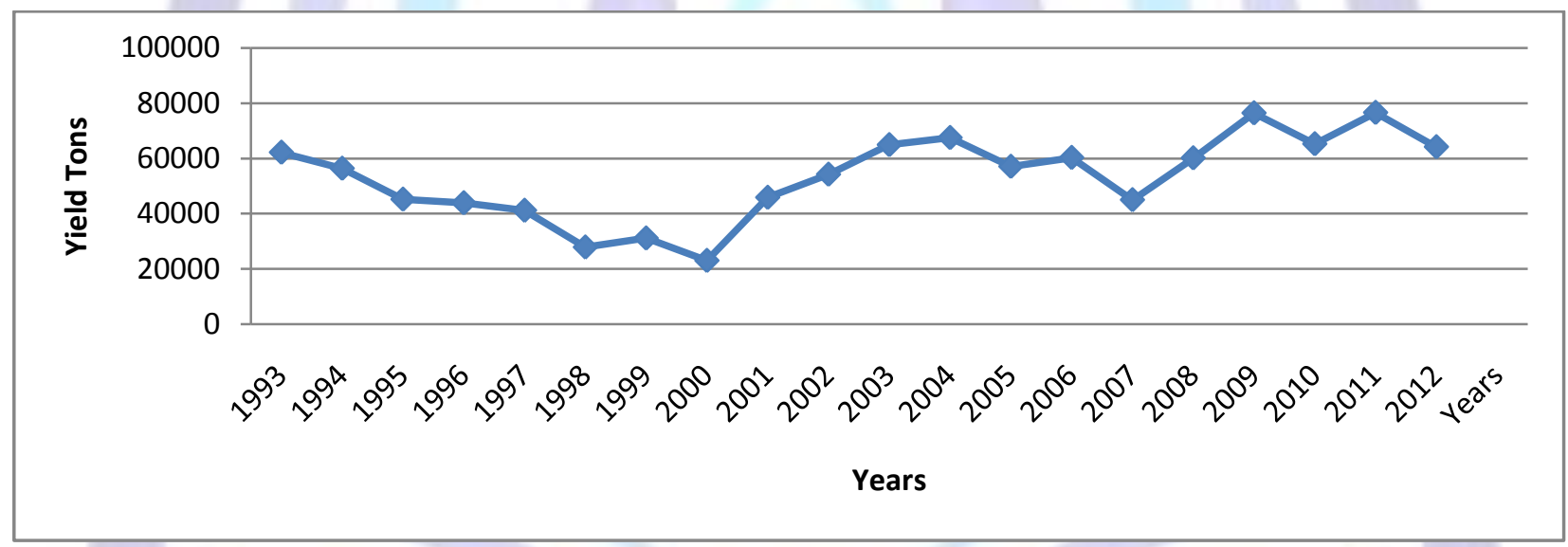

Source: Computed by the author

\section{Analysis of the effect of some climatic variables on cocoa production}

The regression model was used to analyse the effect of some climatic variables on cocoa output. Three functional forms linear, semi-log and double log were tried using ordinary least squares (OLS) estimation technique under the assumptions that data fulfilled the assumptions of multiple regression model. These assumptions include absence of multicollinearity among explanatory variables, normally distributed error term with zero mean and constant variance and non-auto regressive disturbance (Koutsoyiannisi, 1997). The estimated functions were evaluated in terms of statistical significance and magnitude of the coefficient of multiple determinations $\left(R^{2}\right)$, the F-value, and the magnitude of standard error. Based on these statistical and economic criteria, the double log functional form was selected. The result revealed that theminimum temperature and rainy days were statistically significant at $5 \%$ each, implying that these two variables greatly influence the output of cocoa in the study area. Also, the coefficients of maximum temperature and minimum temperature had positive relationships with cocoa output in the study area. This indicated 
that an increase in any of these variables will bring about increase in cocoa yield (due to increased photosynthesis) while the coefficients of relative humidity, rainfall and rainydays had negative relationship with cocoa output in the study area. This implies that an increase in any of these climatic variables would bring about decrease in cocoa yield due to humid condition that normally result in black pod diseases. From the result, it was clear that a coefficient of multiple determination of 0.672 revealed that, $67 \%$ variations of cocoa output is explained by the independent variables in the equation.

\section{Table 3: Result of the regression model on the effect of climate change}

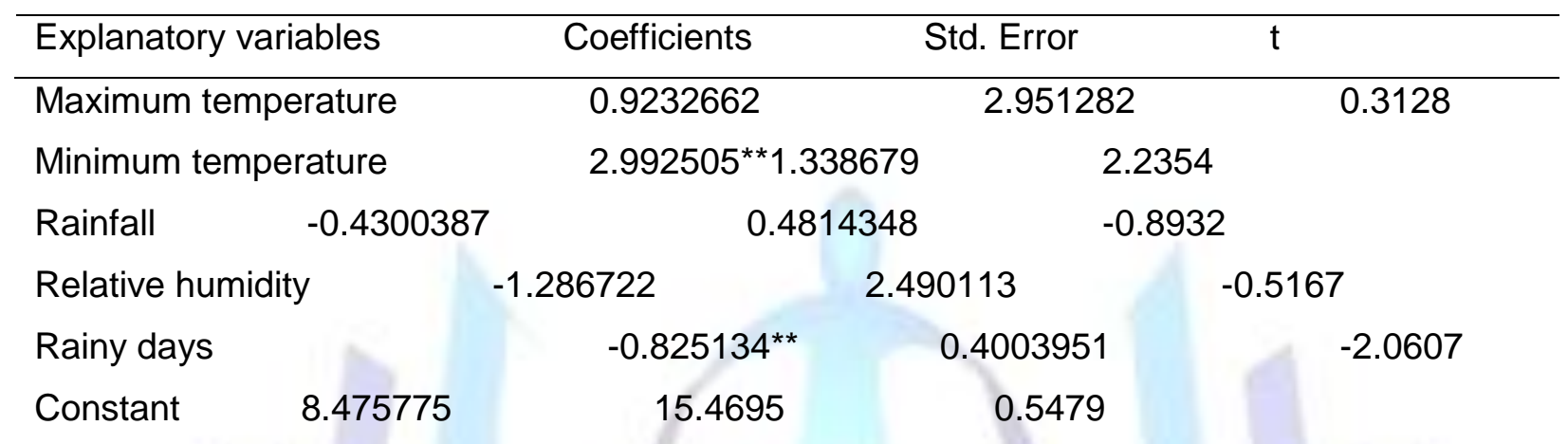

Source: Field Survey, 2013

${ }^{* *}$ Significant at $5 \%$

$R^{2}=0.4620$

Adjusted R Square $=0.3412$

\section{Major Coping Practices Commonly Used among Cocoa Farmers in the Study Area}

As indicated in figure 6, majority of the farmers (90.6\%) identified the use of chemicals as a major and popular means of adaptation strategy used in the study area. The greater use of chemicals as an adaptation method could be due to its effectiveness in preventing fungal diseases which is a major treat to cocoa farmers. Irrigation was observed to be the adaptation least practiced among the major adaptation methods identified in the study area. The reason suggested by the farmers was the consistency in rainfall over the years which have caused reduction in the use of irrigation practices. The farmers also believed so much that prayer is one of the major measures used to combat climate change. Other adaptation methods used are planting different crops and varieties, crop and income diversification, mulching, irrigation, different planting date and monitoring weather. 


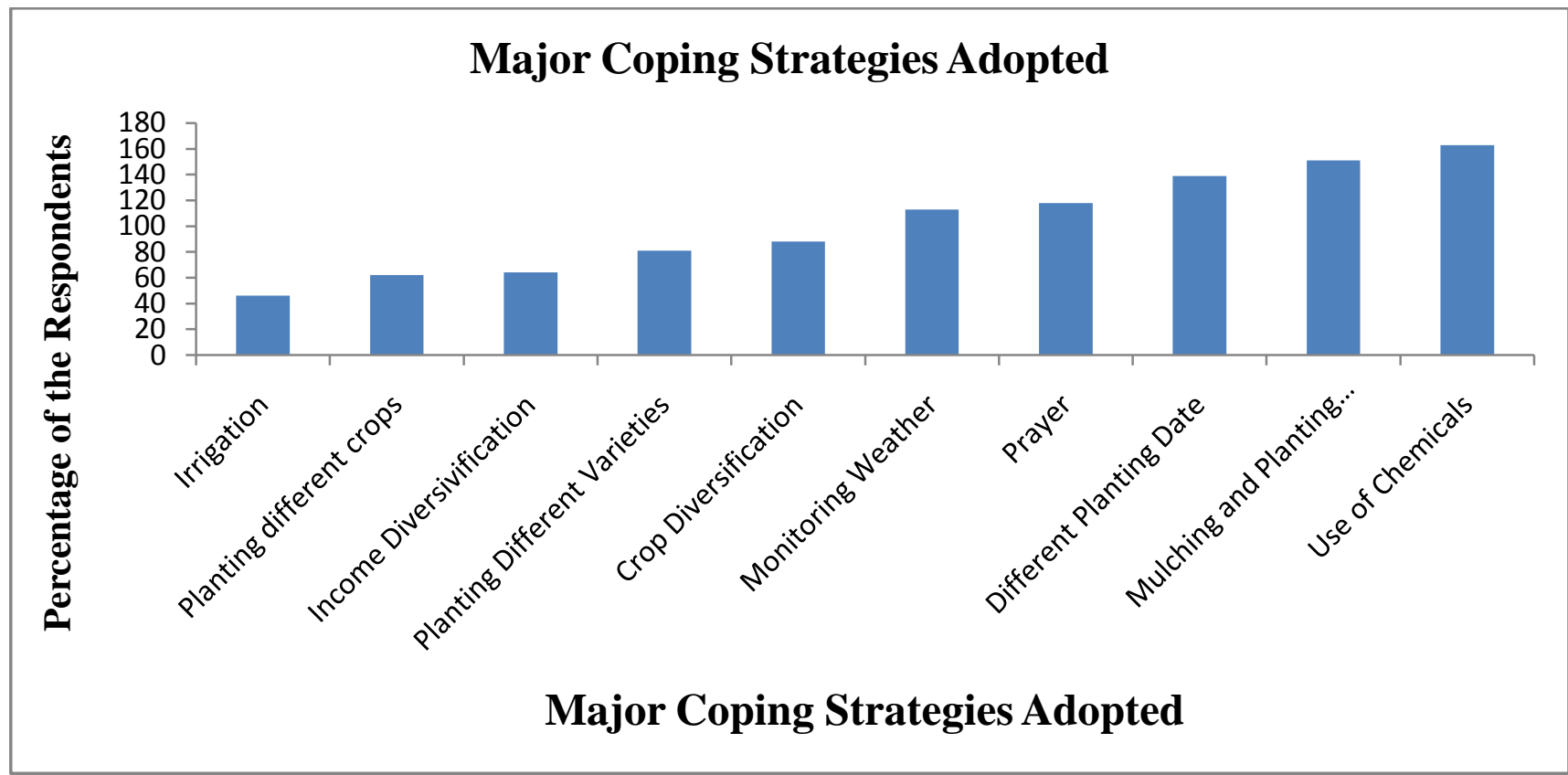

*Multiple Responses

Figure 11: Shows Major adaptation Measures in the Study Area.

Source: Field Survey, 2013

\section{Factors Influencing the Coping Strategy Adopted by the Farmers using Tobit Model}

This section presents the results of Tobit model that showed how socio-economic characteristics of the farmers affected their use of adaptation measures. Adaptation was measured in terms of the number of strategies used by a respondent.The likelihood estimates of the Tobit model indicated that chi-square $\left(X^{2}\right)$ statistic of 79.45 was highly significant $(P<0.0001)$ suggesting that the model has a strong explanatory power. The pseudo coefficient of multiple determination $\left(R^{2}\right)$ showed that 71.9 percent variation in the dependent variable was explained by the included independent variables. This implies that the model showed a good fit to the data. The results revealed that level of education, farm size, access to extension service and farming experience were statistically significant at $1 \%, 5 \%, 5 \%$ and $10 \%$ respectively implying that they were variables found to significantly influence the adoption of coping strategies by the cocoa producing farmers in Ondo State, Nigeria. This result suggests that for every 1 unit increase in these variables there is probability of increase in coping strategies employed. The negative relationship that existed between the age, marital status and primary occupation and the adoption of coping strategies indicates that the higher these variables were, the lesser the adoption, and vice-versa.

\section{Tobit estimate of factors influencing adaptation}

\begin{tabular}{|c|c|c|c|c|}
\hline Explanatory variables & & Coefficients & Std. Error & $t$ \\
\hline Sex & 0.0159115 & 0.456522 & 0.35 & \\
\hline Age & & -0.000924 & 0.0025289 & -0.37 \\
\hline $\begin{array}{l}\text { Marital Status } \\
0.52\end{array}$ & & -0.0095439 & 0.0183723 & \\
\hline
\end{tabular}

Education

$0.0139044^{\star * *}$

0.0036522

3.86

Household size

0.0110669

0.0068044

1.63

Farmsize

$-0.0217012^{* *}$

0.0103619

2.18 
Primary occupation

Acess to extension service

Farming Experience 1.98

Membership of cooperative 0.31

Engage in non-farming activities 0.09
$-0.0014966$

0.0086701

$-0.17$

$0.0281972^{\star *}$

0.0121891

2.31

0.021948

$0.043631^{*}$

0.0053603

0.001642

0.0363907

0.0031904

0.0363907

Constant

$0.5150294^{* \star *} 0.1299945$

3.96

$\begin{array}{lc}\text { Source: Field Survey, } 2013 & \\ \text { Numbers of observations } & 180 \\ \text { LR chi-square } & 79.45 \\ \text { Pseudo } R^{2} & 71.9\end{array}$

\section{Conclusion and Recommendations}

From the socioeconomic point, the study concluded that most of the cocoa farmers in the study area have one form of education or the other, so it could be said that most of the farmers are educated. The study revealed that female cocoa farmers are few in the study area. It can therefore be concluded that majority of the farmers in ondo state are male. Also,the study, having empirically examined the effect of climate change on cocoa production observed that cocoa yield under any treatment depends on climatic factors. Based on the findings from the trend analysis, the study concluded that the highest cocoa production in the study area was in 2009 while the lowest was in 2000. However, between 1993 to 1999, there was a decreasing and fluctuating occurrences in cocoa production which could be attributed to climate change and other factors such like aging plantation, land degradation and rural-urban drift. Heaviest rainfall was recorded between 2009 to 2010 and highest maximum temperature in 2006. There was a sharp increase in humidity in 1998 and in 2004, there was a heavy increase in rainy days. The regression analysis shows that rainy days and minimum temperature had considerable effects on cocoa yield. It can be concluded that an economic amount of rainfall and temperature are important for cocoa production. The study further concluded that high incidence of blackpod diseases and death of cocoa trees are the major problems faced by cocoa farmers in the study area. From the Tobit analysis results, some conclusion can be drawn that education, farming experience, farm size and access to extension service are the major factors affecting the coping strategy adopted by the farmers in adopting to climate change.

It is therefore recommended that Government policies should ensure that fungicides for spraying cocoa tree against cocoa black pod disease are available to farmers at affordable prices. This will help reduce the high incidence of blackpod diseases as that is one of the major problems faced by the farmers in the study area. Also, our research institutions should be revitalized to focus on developing low costs dryers because it was found that most of the farmers complained of inability to dry cocoa pods effectively due to the increasing rainfall and low sunlight for drying cocoa beans. More extension agents must also be employed by government and NGOs in order to encourage and enlighten the farmers on the use of seed varieties that can adapt to different climate conditions. Efforts should be made by relevant stakeholders to educate farmers on climate change, its causes, effects as well as the appropriate coping strategies against it.

Lastly, since rainy days is a very important factor in determining the level of cocoa output, farmers should be encouraged to invest in irrigation facility to provide water especially during dry season. This will ensure availability of water all year round.

\section{References}


1. Adejuwon, S.A. (2004). Impact of Climate Variability and Climate Change on Crop Yield in

a. Nigeria. Contributed paper to Stakeholders Workshop on Assessment of Impact and Adaptation to Climate Change (AIACC): 2-8.

2. Bolaji-Olatunji, K.A., Olufolaju, A.D. and Awe, F. (2010). Climate Change,Adoption and

a. Sustainability Natural Resources Management in Nigeria. Proceedings of the $44^{\text {th }}$

b. Annual Conference of Agricultural Society of Nigeria (ASN). Pp. 1449- 1451.

3. Erelu, O.O. (2008). Cocoa for Health and Wealth. A paper presented in a fourth cocoa Day

4. Celebration in Osun State, Nigeriabetween $22^{\text {nd }}-24^{\text {th }}$ April.

5. Food and Agricultural Organization, (2003), FAOSTAT, http:/faostat/fao.org/default.htm

6. (IPCC) Intergovernmental Panel on Climate Change (2007a). Climate Change 2007; impacts,

a. Adaptation and Vulnerability. Cambridge: Cambridge University Press.

7. (IPPC) Intergovernmental Panel on Climate Change (2007b). Climate Change: Synthesis Report

a. Contribution of working Groups I, II and III to the Fourth Assessment Report of the Intergovernmental Panel on Climate Change. Geneva: Intergovernmental Panel on Climate

8. Change.

9. Medugu, N.I. (2009). The Effects of Climate change in Nigeria. Internet file retrieved on $12^{\text {th }}$

a. Aug 2010 from http:// allafrica.com/stories/200910010424.html.

10. Nabuurs, G.J.,et. al,2007: Mitigation. Contribution of working Group III to The fourth Assessment Report of the Intergovernmental Panel on Climate Change

11. Nigeria Meteorological Agency (NIMET). Nigeria: Climate Review Bulletin 2010: NMA Abuja.

a. And Economic Sustainability held at NnamdiAzikwe University, Enugu, Nigeria, 12-14

b. June 2007.

12. Obatolu, C.R., Fashina, A.B., Olaiya, A. O. (2003). Effects of Climate Change on Cocoa

a. Production in Nigeria. Proceeding of African Crop Science Conference Lagos, Nigeria.

b. 5 pp 957-959.

13. Oluyole, K.A. (2005). Evaluation of the Economics of Post-HarvestProcessing of cocoa in

14. Cross River state, Nigeria. Journal of Agricultural, Forestry and the Social sciences

a. $3(2): 58-64$.

15. Oluyole, K.A. and sanusi, R.A. (2009). Socio- economic Variables and cocoa production in cross

a. Rivers state, Nigeria. Journal of Human Ecology. 25(1): 5-8

16. Opoku, I.Y., Akrofi, A.Y., Appiah, A.A. (2007). Assessment of Sanitation and Fungicide

17. Application directed at Cocoa Tree Trunks for the control of Phytophthorablackpod

18. Blackpod infections in pods growing in the canopy. Eur. J. plant pathol. 2007:117: a. $167-175$.

19. Oyedele, J.O. (2007). Enhancing the sustainability of cocoa gowing Nigeria. A paper presented at

20. the ICCO roundtable congress on sustainable World cocoa Economy at Accra, Ghana,

a. $3^{\text {rd }}-6^{\text {th }}$ October.

21. Pouliotte, J., Smit, B., and Westerhoff, L. (2009). Adaptation and Development: Livelihood and

a. Climate Change in Subarnadad, Bangladesh. Climate Change and Development, 1, 31-46.

22. doi: 10.3763/cdev. 2009. 0001.

23. Tanner, T., and Mitchell, T. (2008). Entrenchment or Enhancement: Could Climate Change

a. Adaptation Help to Reduce Chronic Poverty? Institute of Development studies Bulletin Volume 39 (4 September), 6-15.

24. Wilcox, M.D and P.C. Abbott (2004). Market Power and Structural Adjustment. The case of west

25. African Cocoa Market Liberalization. Paper presented at the American agricultural 
ISSN 2321-1091

Volume $10 \mathrm{Number} 2$

Journal of Social Sciences Research

a. Economics Association Annual Meetings Denver, Colorado, $1^{\text {st }}-4^{\text {th }}$ August.

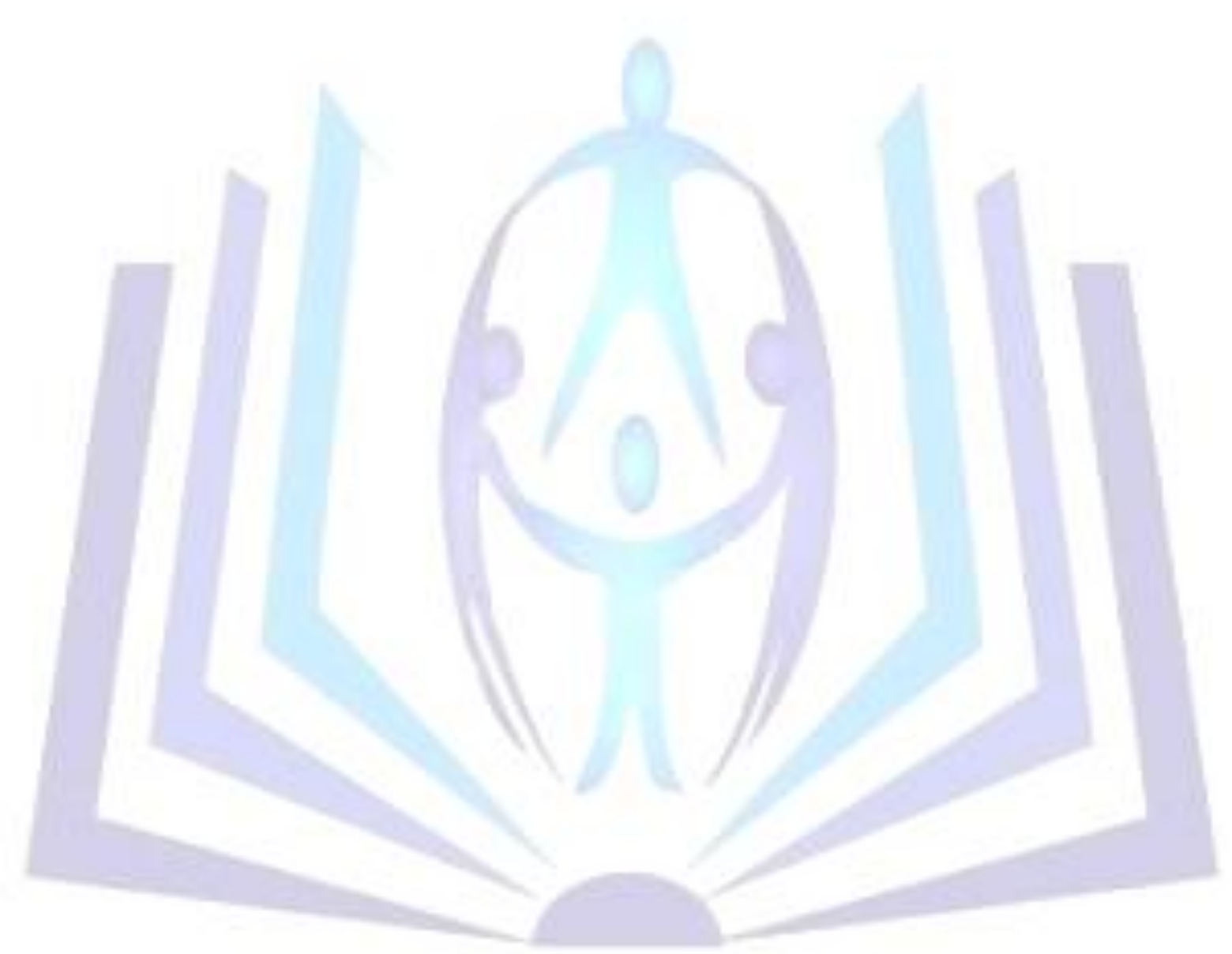

